WILLIAM SAYERS

Cornell University, Ithaca

ws36@cornell.edu

\title{
TWELVE ENGLISH ETYMOLOGIES FROM THE SOCIAL MARGINS (PART 1)
}

Keywords: popular speech, lexicography, English etymology

\begin{abstract}
Etymologies are proposed for twelve previously unexplained English words from working-class or underclass English vocabulary. Treated in Part 1 of this study are cod as 'dupe' and codswallop, mollycoddle / mollycot, natty, and yokel. Common features are isolation, extended use, pejoration, and treatment by lexicographers with varying degrees of proscriptiveness and by word buffs with enthusiastic amateur etymologizing.
\end{abstract}

\section{Introduction}

The search capabilities of the OED online, the electronic version of the Oxford English dictionary (henceforth $O E D$ ), allow the identification of the still substantial number of English words that are without satisfactory etymologies or explanation of origins. ${ }^{1}$ Many of these would appear to have other features in common. They are often semantically and structurally isolated, and lack transparency within the context of words with related meanings. They often appear to reach mainstream English at a relatively late date by way of slang and varieties of underclass speech (if one may be permitted a qualifier drawn from the professional vocabulary of earlier

1 Relevant entries in the OED were accessed in October, 2019, at https://www.oed.com. Material quoted from this reference work may be lightly edited, with ellipsis indicated by suspension points. None of the entries for words examined in this study has been fully "updated" (the dictionary's term) in the latest online iteration. 
editors of the dictionary) or vocational semi-cryptolects. ${ }^{2}$ Twelve lexical notes, several of a quite speculative nature, follow below. Their findings invite a return to these initial considerations by way of conclusion.

Natty: The OED defines the adjective natty as 'of a person: exhibiting or characterized by dainty tidiness, taste, or skill, esp. smartly and fashionably dressed. Also occasionally of a person's actions or behaviour', and 'of a thing, esp. an item of clothing: neatly smart; trim, fashionable; cleverly designed or made. Also occasionally of a person's actions or behavior. In early use perhaps with a sense of crafty, cunning'. First attestations of the word date from the late eighteenth century. The origin of the term, however, is given as "uncertain", with the speculation "perhaps compare neat adjective".

Yet the OED's first recorded instance of natty, from an early dictionary of urban underclass slang, Francis Grose's A classical dictionary of the vulgar tongue from 1785 , points in a different direction from sartorial elegance. Grose glosses natty with 'Natty lads, young thieves or pickpockets'. It may be speculated that young pickpockets found it advantageous to approximate the dress style of their prospective victims, so as not to attract attention. On the other hand, many of the slang terms recorded by Grose and others, e.g. the anonymous B.E. (1699), seem arbitrary assignments of clever phrasing to various criminal and socially marginalized specialties, seen here in the assonance of the near-rhyme nat-/lad. Nonetheless, sharp dressing in an approved insider style does seem behind the gradual melioration in the use of the term natty, a move upscale to monied men-about-town. Many slang words, originally marked as cryptolalic but not overly judgmental, are assumed into regular English in an arch or ironic manner, often in personal correspondence, but then shed their plebian origins and are understood positively. A few decades after the first attestation, natty would appear to have lost its raffish currency and have been absorbed into mainstream English, still with associations of youth and male dress style. ${ }^{3}$ In a satirical "ballad", Shelley writes "As natty a beau, As Bond Street ever saw" (Forman 1877 [The Devil's Walk]: ii).

2 With the $O E D$ at one end of the lexicographical spectrum one might consider the many dictionaries of English slang at the other. But from the perspective of present needs, etymology and historical development are seldom their prime concern. To be noted among these, with their inevitable affect of immediate datedness, are Goldin (1950), Granville (1962), Partridge (1968, 1977), Landy (1971), Patrtridge, Simpson (1974), Wentworth, Flexner (1975), Pearl (1980), Spears (1981, 2000, 2006), Partridge, Beale (1984), Green (1985, 2000), Chapman, Wentworth (1986), Ayto, Simpson (1992, 2008), Lighter (1994-), Chapman (1995), Ayto (1998), Dickson (2006), Patridge et al. (2006), Dalzell, Partridge (2009). There is naturally considerable overlapping among these works, not to say outright borrowing. Ironically, the etymologies proposed by the best known of slang lexicographers, Eric Partridge, are to be viewed with caution. These works are cited below when relevant and even earlier collections of underclass vocabulary are noted.

3 The meanings of many words shift from personal characteristics to outward appearance (cf. smart). On the phenomenon of words from particular lexical fields shifting meanings in similar fashion, see Lehrer (1974) and other studies by this author. 
Since the OED's "uncertain" would be the judgment levied after a review of a possible source in Old English, Old Norse, Anglo-French, and Netherlandic, the search must be taken farther field - but in reality not too far. ${ }^{4}$ Irish-speaking immigrants to British urban centres left a more substantial mark on popular speech than reference works often admit to, probably greater than the contribution of Anglo-Romani in a roughly comparable situation (Sayers 2007, 2008, 2010, 2011, 2016, 2017). In the case of natty as used by speakers of Grose's "vulgar tongue" we may note Irish nath, defined by lexicographer Father Patrick Dinneen (1927, s.v.) as 'a phrase, saying, kenning or adage; a cant word'. The derived adjective nathach was used of one whose speech was marked by the cant lexicon and perhaps by ready wit. The anglicized form natty would then have been self-referential, a slang word to designate someone competent in slang speech. Yet this leaves unexplained the word's use in reference to style of dress, unless, once established as a vogue word, it entered the semantic field of neat.

In England, another Irish word may have influenced this development and may account for the association with clothing as reflected in the recorded use of natty. This is snáithe 'thread, yarn'. Under certain morphological and syntactic conditions, Irish initial $s$ - undergoes lenition and is resolved as /h/, so that snáithe, as a simplex or with a suffix to form an agent noun or adjective, would have sounded something like /hnaihe/. We should have to imagine a metonymic phrasing like the familiar modern threads 'a suit of clothes', if this Irish word were judged to have influenced the emerging natty in its reference to smart apparel. Here, admittedly, semantics makes for a better etymological argument than the phonetics. Also worth at least a mention is Shelta, the cryptolect of Irish travellers, in whose vocabulary the sound sequence is often reversed, and consonants added or dropped. Thus, Irish snáithe 'thread' appears as nāk 'stitch', as in the phrase "not a stitch of clothing" (Macalister 1937: 206). Irish tan 'thin, slender' may also have had currency as nat with the "natty lads", seen above, whose slim builds might be thought an advantage in picking pockets and making off.

Yet another item of dress deserves consideration in exploring the possible origin of natty. The hulls of early Scandinavian war- and cargo-ships were constructed on the clinker principle, by which the long strakes or planks overlapped from the keel upwards and were fastened together with iron nails and rivets. The rivet heads, creating a patterned effect, seem to have contributed to one designation of the trading vessels, knorr, a term related to English gnarly (Sayers 1996). Another name was knattarbarki 'studded boat', preserved in Middle Irish as cnaturbarc (Quin 1913-1976; Cleasby et al. 1957). The base image here, again referencing the rows of rivet heads, is of the button, Old Norse knattr/knappr 'stud, button, knob, ball'. Whether as decorations or fasteners, urban youth in early eighteenth-century London may have worn some kind of class insignia (although surely not one that identified them as thieves), so that natty lads may have had its start in a notion of button boys.

Old French had a variant of matte in the form of natte that referred to a braided rug or other cover but it does not figure in reference to dress (Rothwell 2006). 
English dialect records the term knappal 'a boy from about ten to sixteen years of age'. Natty, too, in its usual senses is well represented in English dialect and this might be thought to argue against its origins in urban slang (Wright 1898-1905, 4.232, s.vv. knappal, natty).

Traditional dictionaries of slang seem to become dated by the moment of their appearance in print, an obsolescence alleviated today in online reference works such as the Urban dictionary, although entries here reflect street use and not the analysis of professional linguists. From pickpockets we move to a contemporary term for innocents on the eighteenth-century social scene and other considerations of clothing.

Cod 'fool, dupe; mock, bogus': In his recently published Seven types of atheism, John Gray breathes fresh argumentative life into a moribund word that originated in the slang register of late seventeenth-century England (italics added):

If Comte's nineteenth-century cult of science produced an ersatz religion joined with the pseudo-science of phrenology, [Richard] Dawkins and his disciples have embellished Darwinism with the cod-science of memes - units of information that compete for survival in a process of natural selection like that which operates on genes. (Gray 2018: 52)

The OED has a number of entries for the form cod, both nouns and verbs. Best known of these is, of course, the ocean fish, Gadus morrhua, the etymology of which has long been uncertain (OED, s.v. cod, n. ${ }^{3}$; see Sayers 2002). Other significations are, briefly, the narrow closed part or bag at the lower end of a trawl-net or other fishing net; the bearing of an axle; river mud with shells. A separate entry is given for cod identified as 'a slang appellation applied to persons, with various forces'. The dictionary continues: 'a joke; a hoax, leg-pull; a parody, a "take-off”(...) Also attributive or quasi-adj., parodying, burlesque; "mock"”. It is under the rubric of the last-named that Gray's remark should be read. Under "Etymology" the dictionary states: "In

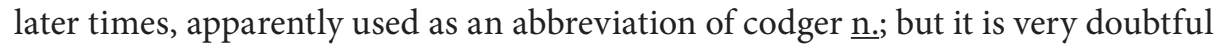
if this is the origin, since it appears much earlier than codger".

The earliest attestation of cod in these senses is from 1699 in A new dictionary of the terms ancient and modern of the canting crew, authored under the initials B.E.: 'Cod (...) a Fool'. It is not until 1708 that this cod appears in a literary context: "O what an honest Cod was this same Ædituus" (OED from Motteux 1737, v.v. 18). The senses of 'joke' and 'bogus' do not appear until the early twentieth century. Slightly earlier are instances of cod as a verb, with the related meanings 'to hoax, to take a "rise" out of'; to humbug, impose upon. (...) to play a joke, to 'kid', to sham; to burlesque' (OED).

5 Cf. "cod-scientific": 13, "cod-philosophy": 51. 
In renewing the inquiry into the origins of the latter cod, one may consider early alternatives to the term. One popular slang term from the 1700 s was coney-catching, in which the coneys or rabbits were the gullible who ventured into underclass areas of London - men on the town, young rakes, and others less fortunate (B.E. 1699, 2010: 42, 'cony, silly fellow'). ${ }^{6}$ Those who preyed on them were confidence tricksters and the present phrase con man may owe something to coney as well as confidence. Since another term for a fool was cod's head (Partridge 1974), ${ }^{7}$ one might image that to cod involved bringing in a sucker as one would bring up a codfish on a long line. A rather different origin, however, will be explored in the following.

Men's fashions in the late sixteenth century featured doublets on which the lower part of the front was stiffly quilted and projecting. These "peasecod-bellied" items of dress are thought to have been modelled on the breastplate of earlier body armour. A folk etymological explanation of the name invokes peacock but the image is more surely that of a pea cod or pod, with its arced, spine-like seam. Just as the lower part of the doublet fakes the true contours of the man's body, so the ruse that took in a mark was in the nature of an illusion. ${ }^{8}$ But this explanation may be too speculative to command credence. Another image or figurative use of cod was also in play in the late sixteenth century and provides the clue to the etymology of cod 'hoax'. The entry for cod in B.E.'s slang dictionary is fuller than the excerpt in the $O E D$ and reads as follows:

Cod, a good sum of money; also a fool. A neer Cod, a silly, shallow Fellow. A rum Cod, c. a good round sum of Money. A jolly or lusty cod, c. the same. An honest Cod, a trusty friend. (B.E. 1699)

Cod as a sum of money may be derived from the cuid '(one's) part, share, money' of Irish-speaking immigrants to London and other cities but may equally well have come from the image of the bag-like fishing net. Concerning the etymology of this cod the OED writes:

Old English $\operatorname{cod}\left(d<\right.$ Old Germanic type ${ }^{\star} k u d d o-z$ : compare early modern Dutch kodde, 'coleus, testiculus' (Kilian), Old Germanic type ${ }^{\star} k u d d o n-$, the source of the closely related $\underline{\operatorname{cod} \mathrm{n}^{2}}$ [axle bearing]. (OED)

With this view of origins, the victim of the confidence man is "bagged" and is not characterized by age, meanness or crustiness, as would be the case if the term were abbreviated from codger $(O E D)$. In the context of the slang dictionary entry for these several cods, this derivation would entail, in the one case, the transfer of the term for the container (pouch) to its contents (money), and, in another the

6 Note the use of the term in another exposé of slang and thievery, Robert Greene's (1592).

7 He explains cod as shorthand for cod's head, thus a simpleton.

8 B.E.'s dictionary has an entry for codders (40), glossed as 'gatherers of peasecods'. One might imagine this as a figurative reference to scammers and their victims but this is not otherwise borne out in popular meanings for peasecod and there are other entries in the dictionary that point, occasionally and curiously, to a rustic, rather than urban underclass, environment. 
transfer of the term for the ruse or hoax to its victim, perhaps under the influence of the verbal homophone to cod. The fact that money or some other advantage is common to both would have strengthened the association ('fools and their money are soon parted'). The use of cod 'bag' as a term of friendship (B.E.'s third referent, 'honest cod') is another example of lightly depreciatory terms of endearment and familiarity in English (cf. 'old bean'). With this establishment of a common etymology for cod as 'bag-like net' and 'hoax', the OED entries for cod as a noun may be reduced by one.

Codswallop: This rather bizarre-looking and -sounding word is defined by the $O E D$ as 'nonsense, drivel' and is attested only from 1959. It is often met with the qualifier "old", as if the practice or the content of the communication were conventional, however irrelevant. ${ }^{9}$ To commence with the hypothesis that the judgment "Codswallop!" could be pronounced on a cod as a hoax or bogus proposition - the attempted illusion being exposed, as it were - speculation may be advanced on the second element. Although English has a cluster of dismissive assessments of speech acts, with a component from the natural world (hogwash, horse-feathers, bullshit), the discussion stays for the moment with cod not as a fish but a dupe. ${ }^{10}$ This, in turn, may guide a search for the original signification of this second element (whether as simplex or confined to compounds). A prior question, however, is whether the term is to be understood as cod-swallop, cod's wallop, or cods' wallop. Certainly, counterfactual statements (drivel) could well figure in the pitch made to a cod by a coney-catcher or confidence man. If we entertain the possibility that the form codswallop is the product of folk etymology, a number of words on the roots wall-, swall- may be considered as candidates, e.g. to wallow in the now obsolete sense 'to be involved in (error, self-will); to be immersed or engrossed in (some occupation, activity, etc.' (OED). As a noun wallow would signify the act by which a mark could be taken in, deluded by one seeking to take advantage. The evolution would have been from cod-wallow to codswallop. But this, too, is at best a very tentative reconstruction. A more attractive source may be identified in the English dialect term to wally 'to obtain one's ends by means of caresses or flattery' (Wright 1898-1905, 6.372). The con man inveigles the cod with wallying. Common to these and the similar explanations that could be generated is the need to have recourse to some explanatory principle such as folk etymology in order to account for form and meaning. With a first written attestation in 1959 and thus no antecedent in English dialect, one may wonder whether codswallop is not itself a bit of a bogus word, coined fairly recently on traditional models, whether those of urban slang or rustic dialect.

\footnotetext{
9 Not found in Wright (1898-1905).

10 Cod in the sense of 'dupe' as well as 'hoax' was still common in English dialect and slang at the turn of the twentieth century (Wright 1898-1905).
} 
To return to the simplex cod, the observed flexibility in semantics and register is matched by other kinds of transferability: movement across the verbal divide, as it were, from activity to person acted on ( $\operatorname{cod}$ 'hoax' > 'victim of a hoax') or from container to contained ( $\operatorname{cod}$ 'bag' > 'bag of money'). ${ }^{11}$ In his somewhat arch resurrection of cod as 'bogus', Gray (2018) dismisses in lightly vituperative fashion contemporary exponents of a self-styled atheism in which scientific technology and material progress are erected into secular religions with a promise of personal and group salvation. In his view we are not all that far from the pitchmen of seventeenth- and eighteenth-century London. The interface between slang and popular disparaging speech is also explored in the next note.

Mollycoddle: The OED has entries for the form mollycoddle as verb and as noun and adjective. The first is defined as follows: 'to coddle, pamper; to treat in an over-indulgent or excessively protective way'. The noun has two aspects: 1 ) 'a person, usually male, who is mollycoddled; 2) an effeminate man or boy; a milksop'. As illustrations of these two senses the OED offers two citations: "You have been bred up as a molly-coddle, Pen, and spoilt by the women" (Thackeray 1848-1850, I. xxxii: 310), "Jane tells me her husband scrubs all the house for her; what a mollycoddle she has made of the man, to be sure". The causality implicit in this entry would seem to be that a pampered boy or man will take on attributes unmanly in the speaker's eyes and even take up women's tasks. But even with allowance for the prejudices of an earlier age we should find it hard to accept that over-indulgent treatment on the one hand would lead to the hard manual labour of scrubbing floors on the other. In short, there is a disconnect in the semantics of the nominal form mollycoddle.

Variant forms of the noun provide a clue toward explanation. Mollycoddle has a country cousin, mollycot, met in English dialect. This individual is defined as 'a man who performs work typically associated with women, or who concerns himself with domestic affairs' (Wright 1898-1905). Far from overindulged, the man may even be browbeaten in an age before the constraints of gender roles had loosened. The cot of this compound then appears to have nothing except phonetics to do with the coddle of mollycoddle. The earliest meaning of this cot (with a number of homonyms) was 'cotter, one living in a cot', thence the semi-learned comment: "Cotarius (...) the inhabitant of any country cot. Hence a country clown is now called a mere cot, as a citizen ignorant of country affairs, a mere cit" (Kennett 1695, 'Glossary'). But, in the urban slang of London as recorded only a few years later, cot has entered into what even then were more demeaning compounds. In a slang dictionary from 1699 is found: Cot for Cotquean 'a Man that meddles with Womens matter' (B.E. 1699) and a decade later "He's a cot, Still dangling about in the Kitchen" (British Apollo, February, 1711: 21-23). Cot is also found compounded with Betty, providing a synonym for

${ }_{11}$ In the term codpiece, cod refers to the scrotum, piece to the fabric won at the top of hose. 
cotquean (= cot-woman, both elements derogatory), and then, through abbreviation, reverts to an "original" form, cot, the meaning of which had been only 'cotter'.

So much for the mollycoddle as mollycotter. Popular speech often displays a whimsical taste for polysyllabicity but when the components of what might appear to be a compound cannot be individually identified the longish word is even more mysterious. The elements of the verbal compound, molly and coddle, may now be addressed as concerns their individual etymologies. The former appears the simpler to explain. The OED defines a molly as 'a girl, a woman, esp. a lower-class one; (occasionally) a prostitute'. The form moll as a (movie) gangster's girl-friend is met at a later date. These are familiar forms of Mary, used in various compounds, in similar fashion to the Betty seen above. While perhaps a coincidence, it should be noted that Latin mollis was used in medieval British penitential literature as a term for sodomites and effeminate men.

Coddle is more problematic. The OED offers a definition and a tentative origin (in the following the entry is lightly edited and some words are glossed in square brackets):

Etymology: In no Dictionary before Todd 1818 [A dictionary of the English language]. It has been variously conjectured to be the same word as coddle v.1 ['to boil gently'], or to be a variant of caddle v. ['to trouble, disturb, worry'], or of caudle v. ['to dispense a caudle', 'a warm drink consisting of thin gruel, mixed with wine or ale, sweetened and spiced, given chiefly to sick people, esp. women in childbed; also to their visitors']. (...) Of these the last would best suit the sense (...). (OED)

None of this is very convincing. Caudle is certainly attractive, as the OED notes, but the original semantics are narrow, the warming of a concoction to be served a sick person, which are then extended to all such attentive care. ${ }^{12}$

We may rather look to a formal feature of English vocabulary: pairs or threesomes of iterative verbs ending in a geminate consonant and the suffix -le or -er and marked by vowel alternation, from front articulation to back, that situates the form quantitatively or qualitatively on scales from fine to coarse, trivial to substantial, for a kind of synesthesia effect, e.g., pitter/patter, skitter/scatter, jingle/jangle, higgle/ haggle. The verb coddle can be plausibly derived from the noun cod in the sense of 'bag, enclosure', the central idea being all-enveloping personal care (the coddling of eggs may be referred to this etymon, too). The variant with $u$-vocalism, cuddle, attested from 1520 , is then to be seen as an even closer, more somatic contact. The OED otherwise calls it "a dialectal or nursery word of uncertain derivation". Although rather different processes are at work, the vowel alternation within English parallels the various reflexes of Germanic roots. In this instance, English cod and the augmented cuddle has a Swedish cognate in kudde 'pillow', that is, a covering over a soft interior for purposes of comfort.

These tentative conclusions invite a return to the element molly. In English dialect to mull meant 'to break into small pieces, pulverize; squeeze' (cf. mollicrush

12 The antecedent is Anglo-Norman chaudel, caudel (Rothwell 2006). 
'pulverize'), while mool meant, inter alia, 'to be intimate with, have sexual relations with' (Wright 1898-1905, 4.197: 153). ${ }^{13}$ Thus, we have a potential ${ }^{*}$ mully that might combine with coddle in reference to food appropriately sized for a convalescent, and a hypothetical ${ }^{*}$ mully-cuddle for another kind of intimacy.

In summary, mollycot 'a man engaged in women's tasks' seems the earliest form. After the emergence of the verbs coddle and cuddle, the first of these seems to have 'invaded' mollycot, with coddle overlaying cot in some regards, and molly losing its tie to Mary as 'woman' and coming under the influence of Latin mollis 'soft' and its derivatives, and native words such as mull and mool. Dated notions of femininity, effeminacy, and masculinity provided a bridging effect. The resulting fusion produces the earlier noted semantic ambiguity: the mollycoddled is made soft by the indulgence of a nurturer; the mollycot is perceived as effeminate by taking on traditional womanly duties. The question of the ultimate origins of the various elements in play here is matched in interest by the problem of disentangling the multiple subsequent influences to which they were exposed and the affinities that developed with other word clusters. Lexical depreciation is also a factor in the next note.

Yokel: In an entry updated as recently as 2016, the OED defines yokel as: 'an uneducated and unsophisticated person from the countryside; a rustic, a country bumpkin'. In anthropologists' terms, this is an etic, not emic, definition, since whatever may be said of the word itself, the meaning does not originate in the communities whose members are so designated. The $O E D$ states that the etymology is uncertain but goes on to speculate as follows:

(...) perhaps the same word as English regional (Yorkshire) and Scots regional yokel ploughboy, ploughman (apparently < yoke n.1 + -el suffix1), although this is first attested later (1888). $(O E D)^{14}$

Yokel is first attested in English literature in J.H. Vaux's New vocabulary of the flash language, a dictionary of urban slang from 1812 compiled by a convicted thief and swindler: 'Youkell, a countryman or clown'. ${ }^{15}$ Although the OED provides an instance of the word as adjective in Dickens's Martin Chuzzlewit ("None of your steady-going, yokel coaches, but a swaggering, rakish (...) London coach”), it fails

13 In this regard, note moil 'labor, toil' (4.143) and its proximity to molly.

14 The commentary continues in a smaller font as if this were a subsequent addition:

It has been suggested that the word ultimately derives from German regional (south.) Jockel, used in the same way (originally a pet-form of the male forenames Jakob and Joachim), which could have been brought to North America by emigrants, and subsequently (within English) from North America to Britain. However, widespread German immigration to North America did not begin until the mid 19th cent. and there is no early evidence of the word there. There is also no indication that the word might have been borrowed from German directly into British English. (OED)

15 Quoted from the somewhat later Memoirs (...) written by himself (Vaux 1819, II: 227). 
to note that Dickens had earlier used the noun in Oliver Twist, in a Bow Runner's dismissal of yokels as possible perpetrators of a crime. ${ }^{16}$

To return to the question of etymology, the OED's first proposal, that the term is a generalization from the use of yokel for a ploughboy, is certainly plausible and the basic image of the yoke and plough is worth retaining. The etymon yoke has multiple applications in extended and figurative uses, while still invoking the image of a device to harness draught animals to a plough or harrow. In southern England, the word yoke was used of a farm and, qualified with the diminutive suffix -let, as yokelet, was used of a small farm, one which in popular understanding could be ploughed and tilled with a single pair of oxen - a one-yoke farm, in other words (Wright 1898-1905, 6.583: 12, s.v. yoke). ${ }^{17}$ Popular understanding of the form yokelet could have led to a back formation, yokel as the owner or more likely tenant of such a small property (cf. cot, cotter). As reconstructed here, there would originally have been no disparagement in the designation yokel, a man working a few fields (or, with the smaller scale now transferred to the agent, a ploughboy). Today, yokel is no longer a descriptor but a term of dismissal, a generally unsupported charge of rustic unsophistication.

\section{References}

Ayto J. 1998. The Oxford dictionary of slang. Oxford, New York.

Ayto J., Simpson J. 1992. The Oxford dictionary of modern slang. Oxford, New York.

Ayto J., Simpson J. 2008. Stone the crows: Oxford dictionary of modern slang. Oxford, New York.

B.E. (anonymous). 1699. A new dictionary of the terms ancient and modern of the canting crew. London. [republished: Simpson J. (ed.). 2010. The first English dictionary of slang. Oxford]. British Apollo = The British Apollo. 1708-1711. London.

Chapman R. [with B. Kipfer and H. Wentworth]. 1995. Dictionary of American slang. New York.

Chapman R., Wentworth H. 1986. New dictionary of American slang. New York.

Cleasby R., Vigfusson G., Craigie W. (eds.). 1957. An Icelandic-English dictionary. [2 ${ }^{\text {nd }}$ edition]. Oxford.

Dalzell T. Partridge E. 2009. The Routledge dictionary of Modern American slang and unconventional English. New York.

Dickens C. 1838. Oliver Twist; or, The parish boy's progress. London.

Dickens C. 1844. The life and adventures of Martin Chuzzlewit. London.

Dickson P. 2006. Slang!: The topical dictionary of Americanisms. New York.

Dinneen P.S. (ed.). 1927. Irish-English dictionary. Dublin.

Forman H. (ed.). 1877. The poetical works of Percy Bysshe Shelley. London.

Goldin H. 1950. Dictionary of American underworld lingo. New York.

Granville W. 1962. A dictionary of sailors' slang. [London].

16 Dickens (1844, xxxvi: 419; 1838, xxxi). Kathleen Tillotson's (1966: 401-403) edition of the novel lists yokel in an appended Glossary of Thieves' Cant and Slang, which sets out the author's possible written sources, among which Vaux's memoir.

${ }_{17}$ This may reflect an unattested Anglo-French ${ }^{\star}$ jugelet 'small yoke' < jug 'yoke'. 
Gray J. 2018. Seven types of atheism. New York.

Green J. 1985. The dictionary of contemporary slang. New York.

Green J. 2000. Cassell's dictionary of slang. London.

Greene R. 1592. The defence of conny catching. Or a confutation of those two iniurious pamphlets published by R.G. against the practitioners of many nimble-witted and mysticall sciences. London.

Grose F. 1785. A classical dictionary of the vulgar tongue. London.

Kennett W. 1695. Parochial antiquities attempted in the history of Ambrosden, Burcester, and other adjacent parts. Oxford.

Landy E. 1971. The underground dictionary. New York.

Lehrer A. 1974. Semantic fields and lexical structure. Amsterdam, New York.

Lighter J. 1994-. Random House historical dictionary of American slang. New York.

Macalister R. 1937. The secret languages of Ireland. Cambridge.

Motteux P. (trans.). 1737. The works of Francis Rabelais, M.D. London.

OED = Oxford English dictionary online. 2019. [http://www.oed.com].

Partridge E. 1968. A dictionary of the underworld: British \& American, being the vocabularies of crooks, criminals, racketeers, beggars and tramps, convicts, the commercial underworld, the drug traffic, the white slave traffic, spivs. London.

Partridge E. 1977. A dictionary of catch phrases, British and American, from the sixteenth century to the present day. Briarcliff Manor (NY).

Partridge E., Beale P. 1984. A dictionary of slang and unconventional English: Colloquialisms and catch-phrases, solecisms and catachreses, nicknames, and vulgarisms. New York.

Partridge E., Dalzell T., Victor T. et al. 2006. The new Partridge dictionary of slang and unconventional English. London, New York.

Partridge E., Simpson J. 1974. The Macmillan dictionary of historical slang. New York.

Pearl A. 1980. The Jonathan David dictionary of popular slang. Middle Village (NY).

Quin E. (gen. ed.). 1913-1976. A dictionary of the Irish language. Dublin.

Rothwell W. et al. 2006. Anglo-Norman dictionary. [https://medievalindex.org/2019/06/09/ the-anglo-norman-online-hub/].

Sayers W. 1996. The etymology and semantics of Old Norse knorr 'cargo ship': The Irish and English Evidence. - Scandinavian Studies 68: 279-290.

Sayers W. 2002. Some fishy etymologies: Eng. cod, Norse porskr, Sp. bacalao, Du. kabeljauw. - NOWELE 41: 17-30.

Sayers W. 2007. Celtic, Germanic and Romance interaction in the development of some English words in the popular register. - Notes \& Queries 54: 132-140.

Sayers W. 2008. Contested etymologies of some English words in the popular register. Studia Neophilologica 80: 15-29.

Sayers W. 2010. Some 'Alsatian' etymologies from eighteenth-century London. - Notes \& Queries 57: 79-83.

Sayers W. 2011. The etymologies of some terms of disparagement: Culprit, get (and brat), gull, job, niggle, prig, vagrant. - Notes \& Queries 58: 31-42.

Sayers W. 2016. English etymologies from the popular register. [Part I, Part II]. - Studia Linguistica Universitatis Iagellonicae Cracoviensis 133: 171-181, 259-267.

Sayers W. 2017. English etymologies from the popular register. [Part III]. - Studia Linguistica Universitatis Iagellonicae Cracoviensis 134: 7-14.

Spears R. 1981. Slang and euphemism: A dictionary of oaths, curses, insults, sexual slang and metaphor, racial slurs, drug talk, homosexual lingo, and related matters. Middle Village (NY). 
Spears R. 2000. NTC's dictionary of American slang and colloquial expressions. Lincolnwood (Chicago).

Spears R. 2006. McGraw-Hill's dictionary of American slang and colloquial expressions. New York (NY).

Thackeray W. 1848-1850. The history of Pendennis. London.

Tillotson K. (ed.). 1966. Oliver Twist; or, The parish boy's progress. Oxford.

Vaux J. 1819. Memoirs of James Hardy Vaux: Written by himself. London.

Wentworth H., Flexner S. 1975. Dictionary of American slang. New York.

Wright J. 1898-1905. English dialect dictionary. [6 vols.]. London, New York. 